day struggles for survival for underclass Blacks (and whites) is often questioned. The racist exclusion from the process of self-definition is facilitated by the self-exclusion from such participation.

There are frequent references to her mother, the artist Faith Ringgold and her artworks. Later on, accounts of her mother's work in a woman's prison indicate the depth of Wallace's passion and regard for her mother and the difficult work that Ringgold is attempting to do. However, I am not sure where it takes us, since Wallace's analysis of the experience is not theoretically or politically incisive enough. It is all right as far as it goes but I wish that these points were being developed further.

Wallace is at her best when analysing specific cultural phenomena such as Spielberg's The Color Purple, Spike Lee's films and Michael Jackson's videos. This is an important collection for those who seek an insight into the questions raised by Black women's feminism, not only in the USA but in Europe too, since it is still the case that feminism has not worked out how to deal with difference that is not based on gender.

\section{Lola Young}

\section{Dependency and Autonomy: Women's Employment and the Family in Calcutta}

\section{Hilary Standing}

Routledge, London, New York ISBN 0415048397 , £10.99 Pbk

This is a book for which, along with other socialist feminists in the UK, I have waited for nearly a decade. The book is based on Dr Hilary Standing's painstaking survey, since 1979, of the changing role of women in the family life of Calcutta. As in other Indian cities, there has been a visible rise in the number of women seeking and obtaining paid jobs in this city since the early seventies. The trend has been more pronounced among Hindu families who were refugees from East Pakistan (now Bangladesh) after the partition of 1947 , but the phenomenon has now become acceptable even among Hindu middle-class West Bengali households, who traditionally frowned upon women who 'go out' to work specifically in semiskilled or unskilled occupations. Economic desperation partly explains the new situation; women's increased aspiration for themselves also accounts for this change.
It is against this background that Dr Standing sets out to test whether waged employment for women necessarily provides a condition for their greater emancipation. This is a question that has vexed academics, policy-makers and institutions for a long time including, as Dr Standing recounts, Engels on the one hand and the World Bank on the other. It is commonly accepted, and understandably so, that it is economic dependency that mainly structures inequality between men and women; yet it would be simplistic to assume that earning power alone brings autonomy into the lives of working women.

Legal institutions and ideology are just as powerful in determining a woman's position in society and family as is her access to a paid job. Hilary Standing, drawing on the lives, dreams and disillusionment of women she has closely studied, thus concludes that there is more at issue than money or goods. (p. 1)

Hilary Standing explores the significance of images of women in historical, literary and artistic traditions of India. In her study, she skilfully alludes to Tagore's novels to unfold the essentially patriarchal structure of family life in Calcutta. Similarly, she pertinently reminds 
us of Mrinal Sen's now classic film, ek din prati din ('one day every day') which brilliantly catches the extent of the moral panic and policing which was brought to bear on the young unmarried daughter - the sole breadwinner of the family - who had to work late one night and was unable to get a message to her family.

The notions of shame and honour make women - including working women - accept their predestined place in the family. The unequal relationship of power gets compounded as women, in practice, are denied access to parental property. The quality of employment contributes to women's insecurity as well, because the majority of new jobs offered to women have been essentially of a highly casualized nature. The analysis and description of informalization of women's employment, drawing on the work of Nirmala Banerjee and Bela Banerjee, provide invaluable resources to those who, like me, are engaged in research on casualization of women's work.

Thus in a society where marriage alone provides social acceptance and secure housing and a certain amount of financial cushioning, even a middle-class woman hardly dares to incur the husband's wrath. A 46-year-old woman college lecturer thus recounts: 'I can exercise my opinion on any matter such as politics, art or family affairs, but on financial matters I cannot say a word. If I need to buy a book or a sari, I have to ask for it from my husband. At the end of the month, only if all the bills have been accounted for, can I have anything.' (Dipali Gosh, 46year-old college lecturer, Calcutta 1982) (p. 85) Yet, as the book shows, the family never represents an 'unchanging' patriarchal system of power relations; an entry into the job market does alter women's social dependency on male members. A young married clerical worker said, 'I can be much more assertive in my family because they have all benefited from my work'. A recognition of the dynamic nature of intrafamilial relationships makes the book special. It redresses the existing lacunae both in liberal sociology and in Marxist analyses. Whereas liberal sociology fails to account for changes in the forms and relations of family either historically or across cultural contexts, Marxism subsumes the whole issue in an encompassing sweep of class relations.

Dr Standing, in this book, admirably highlights the role that women play as agents of change, both inside and outside the trade unions. In occupations where women have a high female membership, women workers view the trade unions as a vehicle of change. In other fields, however, there is a sense that 'unions are male dominated and rank-and-file male workers are uninterested in or hostile to women making separate demands' (p. 136). The situation has not been helped by the communist and socialist parties either: although the left has dominated the West Bengali legislature politically since the 1960 s, 'women's issues' have been consistently marginalized. Understandably, and in line with wider developments in Indian feminist struggles, 'women's groups in Calcutta have begun to develop analyses of the nature of subordination which also encompass ideology and sexual politics, and thus step beyond the left's confinement to the "Engels answer". (p. 113) The book is interspersed with women's voices not only from contemporary society but also from the beginning of the twentieth century. It thus gives us a glimpse of the development of feminism in this subcontinent refuting the myth that feminism is essentially a Western concept: 'Women must earn ... We must first admit that we are not slaves. Then we must get jobs like lady clerks, lady magistrates, lady judges. We do not get paid for housework. ... Men won't be free till 
women are free.' (Mrs. R F Hussein, 'Ornaments or Badge of Slavery', Mahila (Women), May, July, 1903) Even those who love Calcutta will admit that it is not an easy place for academic investigations. Hilary Standing aptly describes the city as 'simultaneously shocking and exciting'. The scrupulous fieldwork, the basis of the book, took toll of Dr Standing's health and delayed the publication of her study. But it was not in vain. Indeed, it is the long gestation period that has given her an insight into the society she set out to study with empathy, modesty and love. The result is a book which offers a rigorous theoretical framework yet is also full of human experiences and interactions. The study reflects the process of an 'outsider' becoming an 'insider' in the course of her academic research. As someone coming from Calcutta - the city I left to avoid an arranged marriage just like one of the characters of Hilary Standing's book - this is the greatest compliment I can pay to her research.

\section{Swasti Mitter}

\section{Simians, Cyborgs and Women: The Reinvention of Nature}

\section{Donna J. Haraway}

Free Association Books: London 1991, ISBN $1853431397 £ 12.95 \mathrm{Pbk}$, ISBN $1853431389 £ 29.50 \mathrm{Hbk}$

Reading these essays - a collection culled from the prolific output of Donna Haraway in the period 197889 - was a great pleasure. My enjoyment came from a sense of political engagement and intellectual project. I was pursuing the trajectory of a serious feminist thinker who is forever mapping, exploring and challenging established Western conceptual frameworks. Each of the sections had its distinctive delights. Part One documents some of the major shifts in the development of Western biological sciences. Donna Haraway doesn't take any short-cuts as the density of the research and the complexity of the analyses indicates. She captures and deconstructs the layers of the social constructiveness of science with unique energy and insight. Yet or perhaps because of this, she is one of the few individuals who can point to the changes in the beast. She really does have her finger on the pulse and is thus able to highlight meta-patterns. The essays in Part Two present a reader of an impressive range of cultural stories: from scientific stories to those of Buchi Emecheta. Across that range, Haraway is forging new tools as both reader and teacher - reflective and questioning, insisting on the plurality of readings. Part Three presents a series of broad reflections on politics at the end of the twentieth century - the politics of: sex/gender; language; socialist-feminism; knowledge; bodies; scientific medicine; etc.

In style and content these essays stand firmly against epistemological imperialism in any form. Contestation is possible at many levels and these essays both are, and encourage, contestations. As Donna puts it, her concerns are both 'dominations' and 'possibilities' (p. 154). Yet she recognizes the complexity of twentieth-century politics and refuses short-cuts which evade that complexity. There are no privileged agents or pure starting-points as she emphasizes in her comments about the key categories of 'women' and 'nature': 'Nature is constructed, constituted historically, not discovered naked in a fossil bed or tropical forest. Nature is contested, and women have enthusiastically entered the fray' (p. 106). A zany optimism which readers are likely to love or hate pervades the whole collection. 